\title{
Germany's Approach to Resolving the Conflict in Mali
}

\author{
V. S. Mirzekhanov ${ }^{a, b, *}$ and Ph. O. Trunov ${ }^{b, * *, *}$ \\ ${ }^{a}$ Institute of World History, Russian Academy of Sciences, Moscow, 119334 Russia \\ ${ }^{b}$ Institute of Scientific Information for Social Sciences, Russian Academy of Sciences (INION RAS), Moscow, 117418 Russia \\ *e-mail: lum62@yandex.ru \\ **e-mail:1trunov@mail.ru
}

Received February 1, 2021; revised February 1, 2021; accepted March 24, 2021

\begin{abstract}
In this century the nature of many conflicts has changed: instead of common interstate feuds, the world has faced intrastate conflicts but with an international background. The active participation of nonstate actors in modern conflicts has made them much less manageable and their resolution much more complicated, including the efforts undertaken by international intermediaries. In the middle and the second half of the 2010s, the countries of the West, first of all, France and Germany, focused enormous efforts on resolving an armed conflict in the Republic of Mali. At first glimpse, these efforts contradict the uprising of Mali's military in August 2020 which removed from power the national civil government headed by the incoming president. The questions raised in this article concern what new elements appeared in the course of relaunching the peace settlement in Mali in 2020 and to what extent nonstandard practices meet the interests of the members of the Euroatlantic Community represented by Germany. This country is chosen as an example due to the long-term trend for the growth of its influence in Africa and the World in general.
\end{abstract}

Keywords: armed conflicts, resolution, international terrorism, security, peacemaking, Mali, Germany.

DOI: $10.1134 /$ S1019331621020167

Contrary to other newsworthy occurrences, first of all, the situation in Belarus and also manifestations of crisis in the political-party framework of the collective West, the coup d'etat in the Republic of Mali on August 18, 2020, received very little coverage in the Russian and foreign media. However, the possible minimal negative influences of the consequences of the events in Mali on international security are commensurate with the influence of the specified plotlines. First of all, this is due to the state of things in Mali itself: as shown by the events of 2012-2013, there is a significant possibility that the factor of separatism (first of all, by Tuaregs), reinforced by the poor administration and general weakness of Mali's government system, can turn this state with an area of $1.24 \mathrm{mln} \mathrm{km}^{2}$ into an enormous playground of international terrorism.

Mali's geographical position multiplied by the peculiarities in the spread of instability across Africa has turned this country into a backdoor to the passage of instability extending through Burkina-Faso and

\footnotetext{
\#Velikhan Salmankhanovich Mirzekhanov, Dr. Sci. (Hist.), is Deputy Director of the RAS Institute of World History and Head of the Department of Asia and Africa at the RAS Institute of Scientific Information on Social Sciences (INION RAN). Philipp Olegovich Trunov, Cand. Sci. (Polit.), is a Senior Researcher in the Department of Europe and America at INION RAN.
}

Niger to Libya. After the destruction of Libya's topdown governance in 2011 in the context of civil war and external military intervention by a group of NATO members headed by France and the United Kingdom, the country has turned into an open source of security threats to the countries of the European Union. First of all, these threats are associated with the relocation of basic international terrorist units, that is, terror cells and individual terrorists, uncontrolled flows of refugees from zones affected by armed conflicts, and also explosives, drugs, and weapons smuggling. As proven by the events of 2015-2016, when a similar crisis broke out due to the strengthening position of terrorist groups in Iraq and Syria, the countries of the EU were strategically unprepared for that crisis. The significant successes of terrorist groups, which include the collapse of civilian government even in one of the members of the G5 Sahel (Burkina-Faso, Mauritania, Mali, Niger, Chad), will result in a situation in which a path to instability will be open. This will mean a major negative, albeit delayed effect on the security of Russia.

In the actual circumstances of August 2020, the complete change in the composition of Mali's topdown governance was one of the many examples of unconstitutional actions intended to change the political and party system in different countries around the globe. In our opinion, the common denominator of all 
these phenomena is the currently observed partial and largely extemporaneous unfreezing of political processes around the globe brought to halt with the first wave of COVID-19 pandemic in the spring and summer of 2020. Back then one of the restraints was a significant slump in the political, diplomatic, military, economic, and information ideological activities of a broad circle of international players, top countries included, in terms of countering various threats and challenges to international security. The unfolding situation was fully applicable to the resolution of armed conflicts. Another restraint is the shrinking of the foreign policy resource base the states have at their disposal. The key reasons for this are economic recession, waning financial capabilities, especially in terms of providing official aid to recipient countries, and a rise in domestic sociopolitical issues of donor countries (including those from the Euroatlantic community), which is showcased by attempts to take soaring, even violent actions and rearrange the political and party framework. This make the elites constantly look for new ways of improving the efficiency of their foreign policy efforts.

The ruling class gets trapped between the Scylla of shrinking electroral support (the dynamics of this process is directly proportionate with inefficient and excessively costly actions on the world scene) and the Charybdis of shrinking resources in the context of the complicating situation in the external environment. Thus, the setback in various kinds of peacemaking activities, military ones included, provides ample regrouping and reorganizational opportunities for international terrorist formations, which includes the risk of their switching to active offensive actions in armed conflict zones. Largely determined by the cutback in foreign aid and abrupt waning of global economic ties, the economic depression in the countries affected by these conflicts encourages an inflow of unemployed people to radical forces. Another dangerous tendency is the merger of terrorist groups with organized crime forces, which expands their capabilities significantly, including room for creating crossborder support areas.

This worrying tendency showed itself even before the Pandemic, first of all, in Mali's center bordering on Burkina Faso [1, p. 5]. Whereas the terrorist formations exhibit significant improvements in survivability, the country's government system, including top leadership and security forces (army, gendarmedie, police), exhibits an extremely slow growth of resistance to topical challenges, even with signs of stagnation and decline [2, p. 17]. Therefore, the issue of settlement of armed conflict sees the rising significance of aid from external participants, first of all, by the most influential players facing the difficulties complicated by the COVID-19 pandemic. It is interesting to explore the dynamics indicated by the example of Germany as one of the few countries of the collective West that belong to rising powers. This article is an attempt to study the influence of forceful authority in Mali in 2020 on the evolution in Germany's approach to settling the armed conflict in this African country.

The past five years have seen increasing interest from Russian and foreign researchers in considering the methods used by international players and institutions, such as the UN and EU, to eliminate the center of instability in the Republic of Mali. In the context of the events of August 2020, however, this plot is viewed from an essentially different angle.

The precedent was the state of things, when a coup d'etat, that in no way met the fundamental principles of democracy, occurred in a state where a group of Western countries had taken massive integral (military and political diplomatic) efforts to settle the local conflict since 2013. The countries of the Euroatlantic community, which carry the heaviest burden, are France (it perceives Mali as a country belonging to the zone of its traditional interests) and Germany [2, pp. 12-16]; the latter considers its participation in ensuring the stability of Mali and the Sahel region in general as one of the main ways of its strategic penetration into Africa. Therefore, the following question is natural: Do the events of August 18, 2020, indicate a failure of Germany's policy in Mali and the complete loss of control over the state of things there or, on the contrary, do they provide a window of opportunities for restarting the faltering resolution process?

It should be noted that, methodologically, we adhere to the principle of determinism applied to the theory of armed conflict resolution. This principle means that the point of no return is or is not reached within five to seven years from the moment of starting the resolution. If there is no result, one of the two basic scenarios is implemented. The first scenario is the degradation of the resolution process when the settlement is essentially reduced to maintaining instability with the limits of a certain range (including freeze as one of the options). This means a reduction in the range of instability risks projected from the armed conflict zone onto the outside players. If implemented, this scenario is highly likely to cause new outbreaks of organized violence-the only questions are the time and rate of increase in tensions after another passage through the point of bifurcation. One of the reasons for this is that it is complicated for external powers to maintain their large-scale peacemaking presence, especially military presence, for decades. Thus, Germany sharply reduced the respective quota of its troops in Lebanon (as part of the UN UNIFIL mission), Afghanistan (as part of the UN/NATO ISAF mission), and Somalia (as part of Operation Atalanta) after 3.5, 10, and 11 years upon deploying the first peacemaking units. ${ }^{1}$ However, there were very few cases when those measures were attended by an improvement in the combatant capacities of the

\footnotetext{
${ }^{1}$ Calculated on the basis of the data from https://www.bundestag.de.
} 
national security forces who had to fight against illegal militia formations.

The second scenario is the attempt to restart the resolution process for reaching the point of no return, though later than initially expected. There are several cases when the countries of the West, Germany included, have used this tactic. For example, one of the decisions in the framework of the policy for Afghanistan in the early 2010s was to augment efforts for creating the conditions for the subsequent afghanization (partially similar to vietnamization) of the resolution process. In the early 2000s and mid-2010s, there were several attempts to readjust the search for ways out of the deadlock of the civil war in Somalia aggravated by the activity of the Ash-Shabaab terrorist group. However, it should be acknowledged that those efforts failed to produce the desired results, which was largely due to the unpreparedness and inability of the official authorities and security forces of the conflictogenic countries to take the main burden of fighting against the forces destabilizing the system of government.

\section{Main Results of Germany's Participation in Resolving the Conflict in Mali}

Are there any grounds for interpreting the events in Mali as the implementation of the second scenario but in an essentially different way? Considering the unconstitutionality of the coup d'etat on August 1821,2020 , this question can be answered negatively. To make an exact verdict, however, it is necessary to look at the results of the resolution achieved with Germany's involvement as of the late 2010s and, therefore, the prospects of this process.

Since February 2013, that is, since the moment of joining the resolution of the armed conflict in Mali, Germany has actively used its room for cooperation as a partner in the duo with France with its traditionally strong positions in West Africa in general and in Mali in particular. Thus, Bundeswehr forces were simultaneously included in the European Union training mission in Mali and the African-led International Support Mission to Mali (AFISMA) (converted since 2013 to the United Nations Multidimensional Integrated Stabilization Mission in Mali (MINUSMA)). In the first case, the instructors from Bundeswehr were responsible for training Mali's military units; that is, they participated in the vertical settlement constituent defined as the deep reforming of the system of government and, especially, the security sector. In the second case, Germany reduced its effort in 2013-2015 to providing logistic and medical aid to the partner states engaged in peacemaking as the horizontal settlement component. First of all, Germany provided its assistance to the French combat units involved in Operation Serval aimed to defeat the militant Islamist groups Ansar Al-Din and Al-Qaeda in the Islamic
Maghreb and the associated radical Tuareg separatists [3, pp. 4-6].

Mali's domestic political context, in which Germany decided to deploy its diverse military presence there, is especially telling. Initially, that is, in the winter and spring of 2012, the antigovernment forces consisted mainly of armed Tuaregs, including former military men from the army of Muammar al-Gaddafi. These forces had managed to take control over the enormous, though scarcely populated territories of the Gao, Kidal, and Tombouctou regions. The rebels followed the path of intensive radicalization. The key roles went over to Ansar Al-Din and al-Qaeda in the Islamic Maghreb, joined by the Tuaregs, who exhibited the most uncompromising attitude to the official authorities in Bamako. Outfits of those groups made their way to the capital, which meant that the whole territory of Mali could turn into a huge black hole. The national authorities were unable to resist the antigovernment outfits efficiently, and from March 21 to April 7, 2013, a group of Mali military headed by Captain A. Sanogo removed President Touré and a large part of ministers from his Cabinet from power. The Parliament's speaker D. Traoré, who had gotten into office, lacked legitimacy both in the international community and in the territories controlled by Bamako's official authorities, where a large part of the population demanded that the insurgent military continue in power.

In this respect, on April 6, 2013, the coup d'etat led to a declaration of independence of the State of Azawad covering the territory uncontrolled by the official authorities; however, that declaration received no international recognition.

The very much conditional legitimacy of the new official authorities in Bamako did not prevent France (since January 2013), Germany, and the European Union in general (since February 2013) from providing them with different kinds of aid, including military assistance [4, pp. 3-5]. In similar respective situations in Afghanistan and Somalia in 2001 and 2010, Germany under the auspices of the UN and EU sent Bundeswehr instructors and units there to provide aid to the interim authorities. In that case, the indispensable condition for Germany's increasing the scale of military support was the legitimation of the authorities of the countries which tried switching to a course of post-conflict development. The first measure taken for that purpose in Mali was the presidential elections held on July 28 (first round) and August 11, 2013 (second round), and won by Ibr. B. Keita. However, the elections were held only in Mali's central and southern provinces, whereas the country's north was engaged in active fighting against irregular outfits. Secondly, France and Germany took on the role of joint intermediaries and de facto coordinators of the talks between the official authorities in Bamako and the moderate Tuareg rebels. The talks were held in Alge- 
ria. On May 15 and June 20, 2015 (the two different dates were set due to disagreements among the Tuareg groups), the Parties signed the reconciliation agreements. They were based on the ultimate nullification of Azawad's independence, that is, the agreement for ceding the North of Mali to the jurisdiction of the official authorities in Bamako in exchange for broad cultural and financial autonomy, that is, for the country's federalization. In military matters the agreements implied disarming most of the outfits of moderate opposition to integrate its former combatants into Mali's armed forces to make them international. The agreements also contained a specific clause stating that joint patrols had to be formed in the north of Mali from regular military and local self-defense units [1, p. 5].

The signing of the agreement considered by Germany to be the roadmap for resolving the armed conflict [1, p. 5] significantly increased the legitimacy of not only Mali's authorities but also the presence of foreign peacemaking and training mission units in the country. That fact provided ample opportunities for raising the scale of the Bundeswehr's presence in Mali up to reaching the point of no return. It should be emphasized that the chosen crossover policy remained unchanged, including the vertical (participation of the German military in reforming Mali's security system) and the horizontal constituent (peacemaking activities). Unlike in Afghanistan, where the indicated kinds of activities were undertaken as part of the common ISAF mission, Germany's efforts in Mali were the first ever example of resolving an armed conflict with the help of the Bundeswehr used in parallel in two different task-specific missions under the respective auspices of NATO and the European Union. In our opinion, the innovation stemmed from the wish to avoid an imbalance in favor one of the components, first of all, the focusing on peacemaking activities, that is, the military use of the contingents of the foreign countries involved in resolving the conflict in prejudice of training a sufficient number of battle worthy troops for Mali's national army, policy, and special ops units which had to assume gradually the burden of fighting against illegal militia groups. So what are the peculiarities and results of Germany's participation in solving each of these tasks in Mali as of the beginning of the 2020s?

After signing the 2015 agreement, Germany simultaneously decided to increase its presence in the MINUSMA from 150 military personnel in 20132015 to 650 in 2016 and 1100 in 2018 [6, p. 3] and accordingly to expand the range of tasks. In addition to purely auxiliary measures (logical and medical support to the military forces of partner states), Germany's Parliament authorized the direct participation of Bundeswehr forces in peacemaking activities. The Bundeswehr assumed the role of a framework nation in manning and managing the activities of the multinational MINUSMA forces based in Camp Castor in the city of Gao, the administrative capital of the province of the same name and the former de jure capital of Azawad. In 2020 these forces also included troops from Belgium, Denmark, Ireland, Lithuania, Netherlands, Switzerland, Sweden (replaced with troops from the United Kingdom in 2020-2021), and Estonia [6, p. 6]. Thus, Germany showed its role as a soft leader of the Euroatlantic community in one of the major areas of its efforts to settle conflicts outside NATO's scope of responsibility. The Bundeswehr focused on organizing the guarding and logistic operation of the Camp Castor base and taking tactical reconnaissance measures, first of all, with the help of unmanned aerial vehicles (from midsize LUNA and LUNA NG to big-sized Heron 1) and on the staff management for the sake of the whole mission [6, pp. $3-7]$. It is interesting that, contrary to Operation Serval with a significant nonbattle component, the German forces actively cooperated with the French troops involved in Operation Barkhane but acted in parallel with the latter and renounced the direct forced application of their capabilities not once requested by the official authorities in Paris. Thus, Germany showed that it had a broad autonomy of action within the duo with France in Mali.

A particular focus in using Bundeswehr troops as part of the MINUSMA was directed to the practical implementation of the agreements reached on May 15 and June 20, 2020, which included maintaining the security of the municipal (in 2017), presidential (on July 29 and August 12, 2018), and parliamentary elections (on April 19, 2020) in Mali's northern provinces. The area of operations of Germany's troops would gradually expand from Gao to the Kidal and Toumbouctu provinces. In February and the first half of March 2020, that is, right before the main wave of the pandemic, several garrisons were formed in the cities of those provinces with active political and military support from Germany and the integration of former combatants of weaponized units of moderate Tuaregs in Mali's regular armed forces [6, p. 4]. Those measures were part of the efforts undertaken by Berlin's official authorities to provide external support for the decentralization of administration in the north of Mali [2, pp. 7-11], that is, through actions within the framework of the horizontal settlement constituent.

Germany's military training forces involved in EUTM Mali essentially assumed the framework nation function and made the greatest total contribution to the overall staff count, planning and pursuit of activities, and administration. Thus, Germany's Parliament gradually raised the upper limit level of Bundeswehr troops in the EUTM Mali from 180 soldiers and officers in 2013 to 350 in 2018 [1, pp. 3-4] and to 450 in 2020 [6, p. 3], which reflects a major increase in the scale of activities of the EU's mission. That said, the actual number of military instructors was lower and the difference from the formal upper limit could be as high as fivefold. The learning process started from 
restructuring the subunits by increasing their numbers of active soldiers by reducing the numerical strength of the maintenance forces and by making these units intertribal and included not only combat training but also political education. The servicemen were explained the principles and values of democracy and the practical expediency of adopting them in Mali. The target-setting of those political studies consisted in implanting among the servicemen the sociocultural code of adhering to the country's federal framework and preventing them from partaking in unconstitutional actions [5, pp. 2-3]. The combat training lessons included step-by-step solution of problems rising in complexity, from training an individual combatant to practicing his actions in small bodies (up to a company) and conducting tactical battalion exercises for ultimately merging individual retrained units into a single military mechanism. Beginning in May 2014, Mali's army units were initially admitted for training (the first training cycle of 16 months) in four-battalion groups, and starting in February 2016, they were admitted in eight-battalion groups, with 600 to 650 servicemen in each battalion. It should be emphasized that, after the training finished, those units were provided with officers appointed by the EUTM Mali (first of all, from the Bundeswehr) to monitor political sentiments and observance of human rights with respects to recruits in the force [1, pp. 4-8]. Beginning in 2018 the units trained earlier were admitted for repeated refresher training, considering the renewal of the personnel and replacement of those released from the military with recruits. Therefore, Germany and its EU partners retained diverse forms of at least de jure control over Mali's army military units and subunits. What was the extent of that control?

Mali's military strength, having increased by $20 \%$ since the mid-2010s, reached 20000 soldiers and officers by the beginning of the 2020s [2, p. 11]. As of March 2019 and May 2020, there were more than 13000 and 15000 servicemen, respectively, trained and retained since the launch of EUTM Mali in 2013 [5, p. $2 ; 1$, p. 5]. That meant that, even if the renewed makeup of the units was considered, the minimal fraction of the soldiers and officers trained by the mission (with the retention of control over the level of combativity and political loyalty) ranged from 50 to $60 \%$ of the total number of Mali's military. It should be emphasized that Germany and its partners, first of all, France, had at their disposition built-in means of controlling and monitoring the situation not only in most of the military units (army's body) but in the staff offices as well, including the staff headquarters (armed forces brain). In the second half of the 2010s, the Bundeswehr created an extensive network of advisers in the military administration bodies not only in Mali but in the other countries of G5S as well [7, pp. 6-12].
Germany's Reaction to the Events of August 18-19, 2020: Intervention (Un-)Acceptable?

A logical question arises: Since France and Germany had this extensive system of controlling and monitoring the situation in Mali's army, could they have been unaware of the fact that the mood among Mali's military was to dismiss President Keïta, especially as the mutineers were headed by Colonel Assimi who commanded a special ops unit that was under the close attention of the foreign instructors? We will make a couple of observations before formulating the answer. On the one hand, Camp Gecko, located in the city of Koulikoro in the center of Mali $55 \mathrm{~km}$ away from Bamako, was still the main center of activities of EUTM Mali. The camp was also not far away from Kati, the mutineers' headquarters, where the detained President Keïta was taken to on August 18, 2020. On the other hand, in the spring and summer of 2020 , Germany's government decided to reduce sharply the number of its military personnel in EUTM Mali: their actual number was reduced from 180 soldiers and officers (against the set maximal number of 450 people) on January 6, 2020 [8], to 69 by August 24, 2020 [9]. Can that change be explained solely by the outbreak of coronavirus? In our opinion, the answer is no: in the first wave of the pandemic, Mali was not one of its epicenters. It is also equally important that the number of Germany's military in the MINUSMA acting in parallel remained almost unchanged and grew from 864 in January 2020 [8] to 868 in August 2020 [9].

If we proceed from the data presented, it will be hard to provide objective arguments for this significant reduction in Germany's presence in EUTM Mali. What does this mean? It is impossible to assert that Germany did not control or was at least unaware of the mood among Mali's military, especially as it cooperated closely with France. With no apparent cause, however, Germany decided to reduce significantly in the short-term its influence on Mali's army exactly when Mali's military expressed their clear disappointment with the country's top leaders.

The reaction of Berlin's official authorities to the events of August 18, 2020, is especially telling. First of all, the military's anticonstitutional actions in Mali were to be followed by changes in the administrative personnel of the contingents and groups of consultants and instructors; however, no such thing happened.

Secondly, neither Germany, nor France, nor their partners showed the pursuance of using their contingents in Mali to counter the mutineer forces or at least keep them blocked at the base in Kati. Thirdly, the official authorities of Paris and Berlin did not essentially consider the possibility of reducing and, all the more so, fully scaling back their efforts in any of the directions of resolving the conflict in Mali [10]. Fourthly, Germany's Ministry of Foreign Affairs gave an indicative response to the actions of Mali's military. Of course, it was not at all calm but very restrained: 
Germany's MFA made its first statement only on August 27, 2020 [10], that is, already after the peak of the situation was left behind. President Keïta was released from detention, and the new military authorities from Bamako held a series of meeting with the ambassadors of the United States, France, Germany, several members of the African Union, and Russia and made the reasons for their actions fairly clear [11]. In their response, for example, Germany's MFA focused its attention mainly on the need for releasing from detention the persons detained by the military on August 18, 2020 [10]. It is telling that neither the official authorities in Paris nor their partners in Berlin decided to use their respective contingents in Mali to release Keïta and his closest companions and put the screws on the military who had staged the coup d'etat.

How was it possible to explain that position on the part of Germany? In the late 2010s the resolution process in Mali began to falter and even degrade despite the successes declared by Germany's officials and a significant buildup of efforts in all of the directions. Thus, whereas in the first half and middle of the 2010s the annual costs of using Bundeswehr forces in MINUSMA did not exceed 50 million Euros, ${ }^{2}$ in 2019-2021 they reached almost 320 million Euros despite the difficulties caused by the pandemic [6, p.3]. This amount does not include the annual expenses on the activities of EUTM Mali (by the late 2010s those expenses were about 40 million Euros [7, p. 3]) as well as the official financial aid provided for development purposes and the means spent on improving the efficiency of administration in the center and at the local level, first of all, in Mali's northern provinces [2, pp. 6-11]. However, those rising efforts did not produce the necessary result: it is telling that the grounds actually identical to the main cause of the military's protests on August 18, 2020, was the accusations that Mali's authorities were unable to turn the tide and ensure more peace and security.

What did the difficulties consist in? Compared to the mid-2010s, the terrorist groups have significantly improved their capacities for replenishment with people and weapons and reorganization and regrouping of resources and forces. The role of ISIS $^{3}$ in the Greater Sahara has also increased [12, p. 2]. With the ISIS main forces defeated in Iraq and Syria (the key role in defeating ISIS belonged to a coalition of Russia, the government of the Syrian Arab Republic, and the Islamic Republic of Iran), the aspirations of the terrorist group for recovering its waning potential were manifested in an attempt to reinforce its flank branches. That was shown in Western Africa and in Afghanistan, where those actions were paradoxically suppressed by the Taliban. In Nigeria there was close cooperation between Boko Haram (Western province of the

\footnotetext{
${ }^{2}$ Calculated on the basis of the data from https://www.bundestag.de.

3 Terrorist organization banned in Russia.
}

Islamic State) and the indicated Islamic State in Greater Sahara, which aimed to spread its influence over all of the members of G5S, starting from Burkina Faso bordering on Mali in the south and southeast. The activities of the Islamic State escalated the tension in Mali's central parts, which had been considered relatively peaceful since 2012-2013. Thus, on February 24,2019 , there was a strafing attack on the camp of the EUTM Mali Gecko forces, where the German military made up the main part [1, pp. 4-8].

The merger of terrorist groups with organized crime forces is pretty much the key factor of the increasing crossborder capabilities of the former [ 1 , pp. 5-6]. Risk-bearing per se, this problem is aggravated by the preserved insufficient combativity of several units of Mali's army and errors in using this combativity. Being afraid of mutiny among the military during Keïta's presidency, Bamako's official authorities used small bodies of military forces (up to a company), first of all, the battalion task forces retrained by the EUTM Mali mission, which made their use much less efficient.

How significant were the dissipation and dispersion of the government armed forces as the factors of failing to purge fully Mali's northern provinces of international terrorist groups? Note that the dispersion of forces is exactly what causes a major lack of troops for patrolling, blocking, and exterminating illegal militia groups in the huge and scarcely populated provinces of Gao $\left(170600 \mathrm{~km}^{2}\right)$, Kidal $\left(151400 \mathrm{~km}^{2}\right)$, and especially Toumbouctu $\left(496600 \mathrm{~km}^{2}\right)$. Thus, the number of personnel of the MINUSMA does not exceed 13200 military personnel [2, p. 12] and usually ranges from 9000 to 12000 people most of whom represent contingents of members of the African Union. The number of the French military involved in Operation Barkhane covering all of the members of G5 Sahel, is 5100 [13, p. 2], whereas Mali's army includes 20000 military personnel [2, p. 8]. According to our estimates, if we subtract the forces used outside Mali's northern provinces (in Mali's west and center and in the region's other states, in military and training camps) from this total number, the number of forces concentrated in Toumbouctu, Kidal, and Gao will not exceed 22000 to 26000 people, including 16000 to 19000 people used directly in the field. Nearly half of the troops involved is composed of Mali's military; the way these troops are used, that is, concentrated or dispersed, largely determines the level of ultimate success.

Of course, the use of automated equipment, particularly unmanned aerial vehicles, especially by Germany, makes it much easier to conduct reconnaissance operations, that is, to track the movement of insurgents and their ammunition and weapon supplies, and significantly expands (according to our estimates, by about $20 \%$ ) the practical capabilities of the MINUSMA and government forces. However, this 
mitigates but in no way solves the issue with onsite military presence (in garrisons, cordons, and mobile strike squads) the density of which in the most vulnerable areas is insufficient with the dissemination of government forces-all the more so as, in the actual context of 2019-2020, they faced the need for constantly controlling the situation not only in the northern but also in the central provinces of the country. It is symptomatic that this region was exactly the one in which on August 18, 2020, the mutiny at the special ops unit base in Kati started; this is one of the confirmations of the fact that the military recognize the increased difficulties of peacemaking in Mali. What was the extent of the actual recognition in Germany? Both opposition forces [5] and German analysts, including members of the SWP think tank $[12,13]$, pointed to the degradation of the situation even before and especially in the course of the pandemic; in particular, the degradation was evident in May and June 2020 when the gradual reanimation of political peacemaking processes was observed. This indirectly demonstrated that the officials in Berlin were aware of the need for restarting the resolution process. Its efficiency is exceptionally important to Germany's authorities in the context of the strategic departure from Afghanistan as part of the deal between the United States and the Taliban, activization of terrorist groups in Iraq, difficulties with solving the crisis in Idlib, and the faltering resolution of the conflicts in Libiya and Ukraine.

\section{$* * *$}

Thus, although at first glimpse the de facto coup d'etat in Mali on August 18-20, 2020, is paradoxical, it has appeared beneficial for France, Germany, and their partners in the EU and has opened a window of opportunities for restarting the resolution process before reaching the point of no return. It is not unimportant that, unlike with similar actions taken by the military in late March and early April 2012, the officials from Paris and Berlin did not display any interest in the immediate transition of authority to civilian government from the military, which had formed the National Committee for the Salvation of the People headed by Colonel A. Goïta. In our opinion, this was caused by the complicated task of finding a politician who showed no toxic behavior in his domestic and for- eign policy aspirations and could really change the situation for the better. It is not improbable that the duo of France and Germany will show at least a neutral attitude to the fairly long preservation (for several months) of the National Committee and its partial integration in the future civil government on the condition of a more active fight against counterinsurgency groups.

\section{REFERENCES}

1. https://dip21.bundestag.de/dip21/btd/19/089/1908971.pdf.

2. https://dip21.bundestag.de/dip21/btd/19/180/1918080.pdf.

3. http://dip21.bundestag.de/dip21/btd/18/014/1801416.pdf.

4. https://dip21.bundestag.de/dip21/btd/17/123/1712367.pdf.

5. https://dip21.bundestag.de/dip21/btd/19/191/1919154.pdf.

6. https://dip21.bundestag.de/dip21/btd/19/190/1919004.pdf.

7. https://dipbt.bundestag.de/dip21/btd/19/190/1919002.pdf.

8. https://de.statista.com/infografik/14715/soldatender-deutschen-bundeswehr-nach-mission-im-ausland/. Cited August 28, 2020.

9. https://de.statista.com/statistik/daten/studie/72703/umfrage/anzahl-der-soldaten-der-bundeswehr-im-ausland/. Cited August 28, 2020.

10. https://www.auswaertiges-amt.de/de/newsroom/mali-freilassung-keita/2378680. Cited August 28, 2020.

11. https://www.mid.ru/web/guest/ukraine/-/asset_publisher/HfLxJk5I2xvu/content/id/4302496\#14. Cited August 28, 2020.

12. W. Kinzel, "Mali, der Terror im Sahel und Covid-19. Das neue Bundeswehr-Mandat für die Beteiligung an MINUSMA," Stiftung Wissenschaft und Politik. SWPAktuell, No. 27, 4 (2020).

13. D. M. Tull, "Deutsches und Internationales Krisenmanagement im Sahel. Warum sich die Diskussion über die Sahelpolitik im Kreis dreht," Stiftung Wissenschaft und Politik. SWP-Aktuell, No. 43, 4 (2020).

Translated by S. Kuznetsov 